\title{
PERBANDINGAN HASIL BELAJAR MATEMATIKA DENGAN MENGGUNAKAN DUA KONSEP ANTARA PENERAPAN TIPE JIGSAW DENGAN PEMBELAJARAN KONTEKSTUAL PADA KELAS V SD NEGERI 91 PANRANG KABUPATEN JENEPONTO
}

\author{
Widyastuti, Hasaruddin Hafid, Nasrun. \\ Pendidikan Guru Sekolah Dasar, Fakultas Keguruan dan Ilmu Pendidikan \\ Universitas Muhammadiyah Makassar \\ Iqramsyar34@gmail.com
}

\begin{abstract}
ABSTRAK
Penelitian ini bertujuan untuk mengetahui perbandingan hasil belajar matematika dengan menggunakan model pembelajaran Tipe Jigsaw dan Pembelajaran Kontekstual Pada murid Kelas V SD Negeri 91 Panrang Kabupaten Jeneponto. Penelitian ini menggunakan sampel sebanyak 30 murid pada kelas V SD Negeri 91 Panrang Kabupaten Jeneponto. Sedangkan pengambilan sampel menggunakan tehnik random sampling. Pengolahan data hasil penelitian untuk hasil tes belajar yang digunakan yaitu statistic deskriptif dan uji hipotesis menggunakan uji t. Hasil penelitian menunjukkan bahwa ada perbandingan hasil belajar murid antara model pembelajaran Tipe Jigsaw dan Kontekstual. Variabel yang paling dominan mempengaruhi terhadap hasil belajar adalah Tipe Jigsaw dengan nilai koefisien sebesar 85,3 sedangkan pada model pembelajaran Kontekstual nilai rata-rata kelas yaitu 62.6 artinya apabila murid Kelas V SD Negeri 91 Panrang Kabupaten Jeneponto meningkatkan model pembelajaran Tipe Jigsaw dengan baik dan tepat, maka murid akan semakin menyimpan hasil belajar dalam memory mereka karena diferensiasi tersebut. Berdasarkan hasil perhitungan uji hipotesis dapat disimpulkan bahwa ada perbedaan hasil belajar matematika murid kelas V SD Negeri 91 Panrang Kabupaten Jeneponto dengan menggunakan model pembelajaran Tipe Jigsaw dan Kontekstual, sehingga hipotesis H0 dinyatakan ditolak dan hipotesis H1 diterima.
\end{abstract}

Kata kunci : Hasil belajar matematik; Model pembelajaran Tipe Jigsaw; Kontekstual. 


\section{PENDAHULUAN}

Rendahnya mutu pendidikan di Indonesia, khususnya rendahnya prestasi belajar dan kurangnya motivasi dalam pembelajaran matematika di sekolah merupakan masalah nasional yang harus dipikirkanbersama.Sampai saat ini matematika merupakan mata pelajaran yang dianggapsulit bagi anak didik kita.Siswa merasa bahwa matematika merupakan momokatau sesuatu yang menakutkan untuk dipelajari.

Proses pembelajaran yang kurang baik dapat menyebabkan prestasi belajar siswa menjadi rendah. Tetapi dapat juga terjadi, walaupun prosespembelajarannya kurang baik, bagi siswa yang memiliki kecerdasan yang tinggididuga prestasinya cukup baik. Seorang siswa yang memiliki intelegensi yangtinggi dengan motivasi yang rendah belum tentu memiliki prestasi belajar matematika yang tinggi. Kegiatan pembelajaran matematika mempunyai peranan yang penting untukmengembangkan kemampuan dan keterampilan nalar serta membentuk sikap peserta didik, oleh karena itu proses komunikasi yang terjadi antara guru sebagaipengajar dan siswa sebagai pembelajar dalam pembelajaran harus berlangsung harmonis. Interaksi antar guru dan siswa akan menentukan berhasil tidaknya pembelajaran matematika yang diterapkan.

Oleh karena itu, guru matematika perlu mencari strategi baru untuk memperbaiki proses pembelajaran sehingga hasil belajar siswa optimal. Dari beberapa model pembelajaran yang ditawarkan salah satunya adalah model pembelajaran konseptual. Wardani, Sri (2006:2) menyatakan bahwa belajar konseptual adalah suatu model pembelajaran di managuru menghadirkan situasi dunia nyata kedalam kelas dan mendorong siswa membuat hubungan antara pengetahuan yang dimilikinya dengan penerapannya dalam kehidupan sehari-hari. Selain itu dikemukakan juga penerapan tipe jigsaw yaitu salah satu tipe pembelajaran kooperatif di mana pembelajaran melalui penggunaan kelompok kecil siswa yang bekerja sama dalam memaksimalkan kondisi belajar untuk mencapai tujuan pembelajaran dan mendapatkan pengalaman belajar yang maksimal, baik pengalaman individu maupun pengalaman kelompok. Pembelajaran yang selama ini dilaksanakan oleh guru matematika adalah pembelajaran klasikal dengan menggunakan metode ekspositori.

Oleh karena itu penulis tertarik untuk membandingkan hasil belajar matematika, antara yang pembelajarannya menggunakan model pembelajaran 
konseptual dengan tipe Jigsaw.Penerapan tipe jigsawmenurut Slavin (Ginanjar, 2001:15) "Model pembelajaran kooperatif tipe Jigsaw memberikan kesempatan kepada siswa untuk dapat melakukan kerja sama dengananggota kelompoknya dalam menghadapi persoalan." Sedangkan model pembelajaran tipe konseptual menurut Anita (2003:68) "Salah satu tipe pembelajaran kooperatif yang mendorong siswa aktifdan saling membantu dalam menguasai materi pembelajaran untuk mencapaiprestasi yang maksimal.” Oleh karena itu, model pembelajaran konseptual maupun tipe Jigsaw diduga dapatmeningkatkan aktivitas siswa dan kerja sama di antara anggota kelompok.

Berdasarkan uraian di atas rumusan masalah dalam penelitian ini adalah: (1) Bagaimanakah hasil belajar matematika pada murid kelas V SD Negeri 91 Panrang Kabupaten Jeneponto dengan penggunaan model pembelajaran tipe Jigsaw?, (2) Bagaimanakah hasil belajar matematika pada murid kelas V SD Negeri 91 Panrang Kabupaten Jeneponto dengan penggunaan model pembelajaran Konseptual? (3) Model pembelajaran manakah yang berpengaruh dominan terhadap hasil belajar matematika pada murid kelas V SD Negeri 91 Panrang Kabupaten Jeneponto?. Tujuan penelitian ini adalah mengetahui: (1) Untuk mengetahui bagaimanakah hasil belajar matematika pada murid kelas V SD Negeri 91 Panrang Kabupaten Jeneponto dengan penggunaan model pembelajaran tipe Jigsaw. (2) Untuk mengetahui bagaimanakah hasil belajar matematika pada murid kelas V SD Negeri 91 Panrang Kabupaten Jeneponto dengan penggunaan model pembelajaran Konseptual. (3) Untuk mengetahui model pembelajaran manakah yang berpengaruh dominan terhadap hasil belajar matematika pada murid kelas V SD Negeri 91 Panrang Kabupaten Jeneponto.

\section{Pengertian Belajar}

Belajar merupakan komponen ilmu pendidikan yang berkenan dengan tujuan dan acuan interaksi, baik yang bersifat eksplisit maupun implisit (tersembunyi). Menurut Gagne belajar adalah sebagai suatu proses dimana suatu organisme beruabah prilakunya sebaai akibat pengalaman. Sedangkan E. Garret berpendapat bahwa belajar merupakan proses yang berlangsung dalam jangka waktu lama melalui latihan maupun pengalaman yang membawa kepada perubahan diri dan peubahan cara mereaksi terhadap suatu rangsangan tertentu. 
Dr. Sadik Sama'an (1978: 13) bahwa belajar adalah aktivitas yang dilakukan oleh peserta didik untuk menerangkan, menyelaraskan, mengecam dan mengubah proses kehidupanya menjadi selaras dengan masalah kebudayaan dan unsure-unsur yang bertentangan di dalamnya.

Menurut Sudjana dalam bukunya "Cara Belajar Siswa Aktif dalam Proses Belajar Mengajar" belajar adalah suatu proses yang ditandai dengan adanya perubahan pada diri seseorang. Perubahan sebagai hasil dari proses belajar dapat ditunjukkan dalam berbagai bentuk seperti berupa pengetahuan, pemahaman, sikap dan tingkah laku keterampilan, kecakapan, kebiasaan, serta perubahan aspek-aspek lain yang ada pada individu yang belajar (Sudjana, 1995: 28).

\section{Model Pembelajaran Tipe Jigsaw}

Model pembelajaran kooperatif tipe Jigsaw merupakan gabungan konsep antara pengajaran pada teman sekelompok dalam usaha membantu mempelajari materi yang diberikan oleh guru. Pada kooperatif tipe Jigsaw didesain untuk meningkatkan rasa tanggung jawab untuk pembelajarannya sendiri dan juga pembelajaran terhadap orang lain.

Model pembelajaran kooperatif tipe Jigsaw dikembangkan dan diuji oleh Eliot Aronson, kemudian digunakan oleh Slavin dan rekannya (Slavin, 2008:236).Dalam pembelajaran kooperatif tipe Jigsaw ini, siswa belajar dalam kelompok yang heterogen beranggotakan 4 sampai 6 anak, yang disebut kelompok asal. Setiap anggota kelompok bertanggung jawab atas penguasaan bagian materi pelajaran yang ditugaskan kepadanya, kemudian mengajarkan bagian tersebut kepada anggota kelompok yang lainnya.Masing-masing anggota kelompok yang mendapat tugas penguasaan bagian materi yang dibagikan disebut ahli.

Pendekatan kooperatif jigsaw mendorong dan memberi kesempatan kepada siswa untuk terampil berkomunikasi. Artinya, siswa didorong untuk mampu menyatakan pendapat atau idenya dengan jelas, mendengarkan orang lain dan menanggapinya dengan tepat, meminta feedback serta mengajukan pertanyaanpertanyaan dengan baik. Siswa juga mampu membangun dan menjaga kepercayaan, terbuka untuk menerima dan memberi pendapat serta ide-idenya, mau berbagi informasi dan sumber, mau memberi dukungan pada orang lain dengan tulus. Siswa 
juga mampu memimpin dan trampil mengelola kontroversi (managing controvercy) menjadi situasi problem solving, mengkritisi ide bukan personal orangnya.

\section{Pembelajaran Konseptual}

Pembelajaran Kontekstual (Contextual Teaching and Learning/CTL) merupakan suatu proses pendidikan yang holistik dan bertujuan memotivasi siswa untuk memahami makna materi pelajaran yang dipelajarinya dengan mengkaitkan materi tersebut dengan konteks kehidupan mereka sehari-hari (konteks pribadi, sosial, dan kultural) sehingga siswa memiliki pengetahuan/keterampilan yang secara fleksibel da-pat diterapkan (ditransfer) dari satu permasalahan /konteks ke permasalahan/ konteks lainnya.

Dalam kelas kontekstual, tugas guru adalah membantu siswa mencapai tujuannya. Guru lebih banyak berurusan dengan strategi daripada memberi informasi. Tugas guru mengelola kelas sebagai sebuah tim yang bekerja ber-sama untuk menemukan sesuatu yang baru bagi anggota kelas (siswa). Sesu-atu yang baru datang dari menemukan sendiri bukan dari apa kata guru. Begitulah peran guru di kelas yang dikelola dengan pendekatan kontekstual. Pembelajaran kontekstual (Contextual Teaching and Learning) adalah konsep belajar yang membantu guru mengaitkan antara materi yang diajarkan-nya dengan situasi dunia nyata siswa dan mendorong siswa membuat hubungan antara pengetahuan yang dimilikinya dengan penerapannya dalam kehidu-pan mereka sehari-hari, dengan melibatkan tujuh komponen utama pembelaaran efektif, yakni: konstruktivisme (constructivism), bertanya (questioning), menemukan (inquiri), masyarakat belajar (learning community), pemodelan (modeling), dan penilaian sebenarnya (authentic assessment).

(Contextual Teaching And Learning) pada intinya adalah keterkaitan setiap materi atau topik pembelajaran dengan kehidupan nyata. artinya siswa dihadapkan pada suatu persoalan yang biasa dihadapi di lingkungan, sehingga pada masanya nanti siswa dapat mampu mengatasi persoalan-persoalan yang nyata yang dihadapi di lingkungannya. Oleh sebab itu, melalui pembelajaran kontekstual, pembelajaran bukan suatu transformasi pengetahuan yang diberikan guru kepada siswa dengan cara menghafal beberapa konsep-konsep yang sepertinya terlepas dari kehidupan nyata, akan tetapi lebih ditekankan pada upaya memfasilitasi siswa untuk mencari 
kemampuan untuk bisa hidup (life skiil) dari apa yang dipelajarinya. Hal ini sangat erat kaitanya dengan tujuan pendidikan nasional yang ditetapkan pemerintah.

\section{METODE PENELITIAN}

Metode yang digunakan dalam penelitian ini adalah metode deskriptif kualitatif. Penelitian ini merupakan penelitian survey yaitu suatu penelitian yang mengambil data.Data yang diperoleh dari siswa berdasarkan prestasi atau hasil belajar matematika melalui konsep penerapan tipe jigsaw dan pembelajaran kontekstual.

Populasi dalam penelitian ini adalah seluruh murid SD Negeri 91 Panrang Kabupaten Jeneponto. Pada penelitian ini yang menjadi sampel adalah murid kelas V A dengan jumlah murid 17 orang dan kelas V B dengan jumlah murid 13 orang. Pengolahan data hasil penelitian yang digunakan yaitu statistik deskriptif dan uji hipotesis.

\section{HASIL PENELITIAN DAN PEMBAHASAN}

Pada bagian ini dibahas hasil penelitian mengenai perbandingan hasil belajar melalui model pembelajaran Tipe Jigsaw dan pembelajaran kontekstual pada murid kelas V SD Negeri 91 Panrang Kabupaten Jeneponto yaitu data tentang hasil pengamatan, sedangkan data tentang hasil belajar murid di analisis secara deskriptif kualitatif. Adapun yang di analisis adalah hasil belajar model pembelajaran Tipe Jigsaw dan model pembelajaran Kontekstual serta data perubahan sikap murid secara umum yang diambil melalui lembar pengamatan sikap murid.

1. Hasil Belajar Model Pembelajaran Tipe Jigsaw

Pada model pembelajaran Tipe Jigsaw ini dilaksanakan tes hasil belajar Matematika dengan bentuk pilihan ganda (option).Tes hasil belajar tersebut dilaksanakan setelah penyajian beberapa pokok bahasan. Adapun data skor hasil belajar model pembelajaran Tipe Jigsaw dapat dilihat pada table berikut :

Tabel 1 Statistik Skor Hasil Belajar Matematika Murid Kelas V SD Negeri 91 Panrang Kabupaten Jeneponto Melalui Model Pembelajaran Tipe Jigsaw

\begin{tabular}{|c|c|}
\hline Statistik & Nilai Statistik \\
\hline Jumlah Murid & 15 \\
Nilai Ideal & 100 \\
\hline
\end{tabular}




\begin{tabular}{|c|c|}
\hline Nilai Maksimum & 100 \\
Nilai Minimum & 60 \\
Rentang Nilai & 40 \\
Nilai Rata-Rata & 85,3 \\
\hline
\end{tabular}

Berdasarkan Tabel 1 menunjukkan bahwa skor rata-rata (mean) hasil belajar murid kelas V SD Negeri 91 Panrang Kabupaten Jeneponto setelah dilakukan tindakan dengan model pembelajaran Tipe Jigsaw adalah 85,3 dari skor ideal yang mungkin dicapai adalah 100. Skor maksimum 100 dari skor ideal 100, skor minimum 60 dari skor ideal 100, dan rentang skor 40 dari skor ideal 100 yang mungkin dicapai. Skor rata-rata tersebut menunjukkan bahwa hasil belajar murid kelas V SD Negeri 91 Panrang Kabupaten Jeneponto berada dalam kategori tinggi. Apabila skor hasil belajar murid di kelompokkan ke dalam 5 kategori maka diperoleh distribusi frekuensi nilai seperti yang di sajikan pada table 4.2.

Tabel 2 Statistik Frekuensi dan Persentase Skor Hasil Belajar Untuk Model Tipe Jigsaw

\begin{tabular}{|c|c|c|c|c|}
\hline No & Nilai & Kategori & Frekuensi & Persentase (\%) \\
\hline 1 & $0-39$ & Sangat rendah & 0 & 0 \\
\hline 2 & $40-54$ & Rendah & 0 & 0 \\
\hline 3 & $55-69$ & Sedang & 1 & 6,6 \\
\hline 4 & $70-84$ & Tinggi & 7 & 46,7 \\
\hline 5 & $85-100$ & Sangat tinggi & 7 & 46,7 \\
\hline \multicolumn{3}{|c|}{ Jumlah } & 15 & 100 \\
\hline
\end{tabular}

Berdasarkan Tabel 2 diperoleh bahwa dari 15 orang jumlah murid kelas V SD Negeri 91 Panrang Kabupaten Jeneponto, tidak terdapat murid (0\%) yang berada dalam kategori sangat rendah dan kategori rendah, 1 murid (6.6\%) yang berada pada kategori sedang, 7 murid (46.7\%) yang barada pada kategori tinggi, dan 7 murid (46.7\%) berada pada kategori sangat tinggi. Hal ini disebabkan karena tingginya minat dan perhatian belajar hasil belajar serta proses pembelajaran yang aktif dan menarik.

Nilai rata-rata hasil belajar murid kelas V SD Negeri 91 Panrang Kabupaten Jeneponto pada model pembelajaran Tipe Jigsaw adalah 85.3 dari nilai ideal yang mungkin dicapai murid yaitu 100 berada pada interval 85 - 100. Dengan demikian dapat 
disimpulkanbahwa hasil belajar murid kelas V SD Negeri 91 Panrang Kabupaten Jeneponto setelah dilaksanakan tindakan pada model pembelajaran Tipe Jigsaw berada pada kategori sangat tinggi.

2. Hasil Belajar Model Pembelajaran Kontekstual

Pada model pembelajaran Kontekstual ini dilaksanakan tes hasil belajar melalui model pembelajaran Kontekstual.Tes hasil belajar tersebut dilaksanakan setelah penyajian beberapa pokok bahasan. Adapun data skor hasil belajar model pembelajaran Kontekstual dapat dilihat pada Tabel 3 berikut :

Tabel 3 Statistik skor hasil belajar murid kelas V SD Negeri 91 Panrang Kabupaten Jeneponto pada model pembelajaran Kontekstual

\begin{tabular}{|c|c|}
\hline Statistik & Nilai Statistik \\
\hline Jumlah Murid & 15 \\
Nilai Ideal & 100 \\
Nilai Maksimum & 80 \\
Nilai Minimum & 30 \\
Rentang Nilai & 50 \\
Nilai Rata-Rata & 62,6 \\
\hline
\end{tabular}

Berdasarkan Tabel 3 menunjukkan bahwa skor rata-rata (mean) hasil belajar murid kelas V SD Negeri 91 Panrang Kabupaten Jeneponto setelah pemberian tindakan pada model pembelajaran Kontekstual adalah 62,6 dari skor ideal yang mungkin dicapai adalah 100. Skor maksimum 80 dari skor ideal 100, skor minimum 30 dari skor ideal 100, dan rentang skor 50 dari skor ideal 100 yang mungkin dicapai. Jika skor hasil belajar murid di kelompokkan ke dalam 5 kategori, maka diperoleh distribusi frekuensi nilai seperti yang di sajikan pada Tabel 4 berikut.

Tabel 4 Statistik Frekuensi dan Persentase Skor HasilBelajar Matematika pada Model Pembelajaran Kontekstual

\begin{tabular}{|c|c|c|c|c|}
\hline No & Nilai & Kategori & Frekuensi & Persentase (\%) \\
\hline 1 & $0-39$ & Sangat rendah & 2 & 13.4 \\
2 & $40-54$ & Rendah & 3 & 20 \\
3 & $55-69$ & Sedang & 1 & 6,6 \\
4 & $70-84$ & Tinggi & 9 & 60 \\
\hline
\end{tabular}




\begin{tabular}{|c|c|c|c|c|}
\hline 5 & $85-100$ & Sangat tinggi & 0 & 0 \\
\hline \multicolumn{3}{|c|}{ Jumlah } & 15 & 100 \\
\hline
\end{tabular}

Berdasarkan table 4.4 diperoleh bahwa dari 15 jumlah murid kelas V SD Negeri 91 Panrang Kabupaten Jeneponto, 2 murid (13.4\%) berada pada kategori sangat rendah dan 3 murid $(20 \%)$ berada pada kategori rendah, 1 murid (6.6\%) berada pada kategori sedang, 9 murid (60\%) berada pada kategori tinggi, dan tidak ada murid $(0 \%)$ yang berada pada kategori sangat tinggi.

Nilai rata-rata hasil belajar murid kelas V SD Negeri 91 Panrang Kabupaten Jeneponto pada model pembelajaran Kontekstual adalah 62.6 dari nilai ideal yang mungkin dicapai murid yaitu 100 berada pada interval 55 - 69. Dengan demikian dapat disimpulkan bahwa hasil belajar murid kelas V SD Negeri 91 Panrang Kabupaten Jeneponto setelah dilaksanakan tindakan pada model pembelajaran Kontekstual berada pada kategori sedang.

Dalam penelitian ini diterapkan model pembelajaran Tipe Jigsaw dan Kontekstual yang terdiri dari dua model pembelajaran yang dilaksanakan tiga kali pertemuan setiap tindakan.Penelitian ini membuahkan hasil yang signifikan yakni adanya perbedaan hasil belajar murid kelas V SD Negeri 91 Panrang Kabupaten Jeneponto dapat dilihat pada Tabel 5.

Tabel 5 Perbandingan hasil belajar matematika murid kelas V SD Negeri 91

Panrang Kabupaten Jeneponto pada model pembelajaran Tipe Jigsaw dan model pembelajaran Kontekstual

\begin{tabular}{|c|c|c|c|c|c|}
\hline \multirow{2}{*}{ Model } & \multicolumn{5}{|c|}{ Nilai Perolehan dari 15 Jumlah Murid } \\
\cline { 2 - 6 } & Ideal & Maksimum & Minimum & Rentang & Mean \\
\hline Tipe Jigsaw & 100 & 100 & 60 & 40 & 85.3 \\
\hline Kontekstual & 100 & 80 & 30 & 50 & 62.6 \\
\hline
\end{tabular}

Berdasarkan tabel di atas menunjukkan bahwa setelah dilaksanakan tes dari jumlah murid pada model pembelajaran Tipe Jigsaw memperoleh nilai maksimum 100 dari skor ideal 100, nilai minimum 60 dari nilai ideal 100, rentang nilai 40 sehingga secara klasikal memperoleh nilai rata-rata 85.3 dari skor ideal 100. Sedangkan pada model pembelajaran Kontekstual dari 15 jumlah murid memperoleh nilai maksimum 80 dari nilai ideal 100, nilai minimum 30 dari nilai ideal 100, dari rentang nilai 50 sehingga secara klasikal pada model pembelajaran Kontekstual memperoleh nilai rata- 
rata 62,6 dari nilai indeks 100. Artinya antara model pembelajaran Tipe Jigsaw dan model pembelajaran Kontekstual terjadi perbedaan hasil belajar murid kelas V SD Negeri 91 Panrang Kabupaten Jeneponto. Hal ini menunjukkan bahwa model pembelajaran Tipe Jigsaw lebih efektif diterapkan dalam proses pembelajaran dibandingkan model pembelajaran Kontekstual.

Hipotesis adalah jawaban sementara terhadap masalah penelitian yang kebenarannya masih harus di uji secara empiris.Jadi suatu hipotesis masih merupakan jawaban sementara terhadap suatu permasalahan yang kebenarannya masih perlu adanya pembuktian lebih lanjut.

Adapun hipotesis dalam penelitian ini adalah sebagai berikut :

Ho: Tidak ada perbedaan hasil belajar Matematika murid kelas V SD Negeri 91 Panrang Kabupaten Jeneponto dengan menggunakan model pembelajaran Tipe Jigsaw dan Kontekstual.

H1: Ada perbedaan hasil belajar Matematika murid kelas V SD Negeri 91 Panrang Kabupaten Jeneponto dengan menggunakan model pembelajaran Tipe Jigsaw dan Kontekstual.

Berikut ini adalah langkah-langkah dalam menguji hipotesis :

1. Menentukan standar deviasi Tipe Jigsaw

$$
\text { Standar deviasi }=\sqrt{\sum x^{2}-\frac{\left(\sum x\right)^{2}}{\mathrm{n}}} \frac{\mathrm{n}-1}{}
$$

Standar deviasi $=\sqrt{111200-\frac{(1280)^{2}}{15}}$

Standar deviasi $=\sqrt{111200-(1638400)}$

$$
\frac{15}{15-1}
$$

$$
\text { Standar deviasi }=\sqrt{111200-109226,6}
$$

Standar deviasi $=\sqrt{1973,4}$ 
Standar deviasi $=\sqrt{140,9} \quad$ Standar deviasi $=11,8$

2. Menentukan standar deviasi Kontekstual

$\begin{aligned} \text { Standar deviasi }=\sqrt{\sum x^{2}-\frac{\left(\sum x\right)^{2}}{\mathrm{n}}} & \frac{\mathrm{n}-1}{}\end{aligned}$

Standar deviasi $=\sqrt{63600-\frac{(940)^{2}}{15}}$

$15-1$

Standar deviasi $=\sqrt{63600-(883600)}$

$15-1$

Standar deviasi $=\sqrt{63600-58906,6}$

14

Standar deviasi $=\sqrt{4693,4}$

14

Standar deviasi $=\sqrt{335,2} \quad$ Standar deviasi $=18,3$

3. Menentukan standar deviasi gabungan

$$
\begin{aligned}
& d s g=\sqrt{\frac{(n 1-1) S_{12}+(\mathrm{n} 2-1) S_{22}}{\mathrm{n} 1+\mathrm{n} 2-2}} \\
& d s g=\sqrt{\frac{(15-1) 118+(15-1) 18,3}{15+15-2}}
\end{aligned}
$$




$$
\begin{aligned}
& d s g=\sqrt{\frac{(14 \times 118)+(14-18,3)}{28}} \\
& d s g=\sqrt{\frac{(165,2+256,2}{28}} \\
& d s g=\sqrt{\frac{421,4}{28}} \quad d s g=3,8 \\
& d s g=\sqrt{15,05}
\end{aligned}
$$

4. menentukan nilai hipotesis

$$
\begin{aligned}
& \text { thitung }=\frac{\mathrm{x} 1-\mathrm{x} 2}{d s g \sqrt{\frac{1}{n 1}}+\frac{1}{n 1}} \\
& \text { thitung }=\frac{85,3-62,6}{3,8 \sqrt{\frac{1}{15}}+\frac{1}{15}} \\
& \text { thitung }=\frac{22,7}{3,8 \sqrt{0,13}}
\end{aligned}
$$

thitung $=\frac{22,7}{3,8(0,36)}$

thitung $=\frac{22,7}{1,368}$

thitung $=16,5935$ 


$$
\begin{aligned}
d b & =\mathrm{n} 1+\mathrm{n} 2-2 \\
& =15+15-2 \\
& =28
\end{aligned}
$$

t tabel , $0,05(5 \%), \mathrm{db} 28=1,70113$

$\mathrm{t}$ hitung $\geq \mathrm{t}$ tabel

Berdasarkan hasil perhitungan t-test diperoleh nilai t hitung sebesar 16,5935 sedangkan nilai t tabel pada taraf signifikansi 5 persen dengan $\mathrm{db}=28$ sebesar 1,70113 hal itu berarti bahwa nilai $t$ hitung lebih besar dari $t$ tabel. Karena nilai $t$ hitung lebih besar dari pada t tabel, maka sebagai konsekuensinya adalah hipotesis $\mathrm{H} 1$ “Ada perbedaan hasil belajar Matematika murid kelas V SD Negeri 91 Panrang Kabupaten Jeneponto dengan menggunakan model pembelajaran Tipe Jigsaw dan Kontekstual “ dinyatakan diterima dan hipotesis H0 ditolak.

\section{SIMPULAN DAN SARAN}

Berdasarkan hasil penelitian dan pembahasan, dapat disimpulkan bahwa model pembelajaran Tipe Jigsaw memberikan hasil belajar matematika yang lebih baik pada murid kelas V SD Negeri 91 Panrang Kabupaten Jeneponto. Hal tersebut dibuktikan pada model pembelajaran Tipe Jigsaw nilai rata-rata kelas adalah 85,3. Sedangkan model pembelajaran Kontekstual tidak memberikan hasil belajar matematika yang baik pada murid kelas V SD Negeri 91 Panrang Kabupaten Jeneponto. Hal itu dapat dibuktikan dengan nilai rata-rata kelas yaitu 62.6. Kemudian berdasarkan hasil perhitungan uji hipotesis dapat disimpulkan bahwa ada perbedaan hasil belajar matematika murid kelas V SD Negeri 91 Panrang Kabupaten Jeneponto dengan menggunakan model pembelajaran Tipe Jigsaw dan Kontekstual, sehingga hipotesis H0 dinyatakan ditolak dan hipotesis H1 diterima.

Saran yang dapat diberikan: (1) Hendaknya pendidik mampu menggunakan strategi pembelajaran yang sesuai denga materi yang diajarkan, dan guru juga dituntut untuk dapat menerapkan model pembelajaran dengan benar. (2) Hendaknya orang tua memperhatikan pendidikan anaknya dan memberikan motivasi untuk belajar agar dapat meningkatkan prestasi anaknya sehingga harap orang tua dan guru terhadap keberhasilan siswa dapat 
tercapai. (3) Hendaknya pemerintah lebih memperhatikan sekolah yang betul-betul membutuhkan bantuannya khususnya yang menyangkut tentang pengembangan profesionalisme guru.

\section{DAFTAR PUSTAKA}

Arif S. Sadiman, (1984:11). Proses Belajar Mengajar Pada Hakikatnya, Jakarta : Bumi Aksara.

Oemar Hamalik, (2008:157). Belajar dan Motivasi, Jakarta : Rineka Cipta.

Agus Supriono (2009: 40), Model Pembelajaran, Jakarta : Rineka Cipta.

Mujafar,. (2006). Pembelajaran Matematika, Surakarta : University Press.

Ira Kurniawati. (2003). Metode Pembelajaran Kooperatif, Bandung : Bina Media Informasi.

Sardulo Gembong. (2008). Efektifitas Pembelajaran. Jakarta: Gramedia Widiasarana Informatika.

Dimyati dan Mudjiono.(2006:41). Kegiatan Mengajar. Jakarta: Gramedia Widiasarana Informatika.

Erman Suherman.. (2001:9). Konsep Sosiologi, Jakarta : Rineka Cipta.

Tabrani. (1989:1). Kondisi Belajar, Bandung : C.V. Permadi.

Arikunto, (2006).Prosedur Penelitian Suatu Pendekatan Praktek, Jakarta : Bumi Aksara.

Budiningsih, (2005).Belajar dan Pembelajaran, Jakarta : Rineka Cipta.

Depdiknas.(2005). Teori Belajar. Jakarta: Depdiknas.

Ibrahim, Muslimin et.al. (2000). Pembelajaran Kooperatif, Surabaya : University Press.

Karli, Hilda dan Margaretha S.Y. (2002).Model-Model Pembelajaran, Bandung : Bina Media Informasi.

Lie, Anita. (2005). Cooperative Learning. Jakarta: Gramedia Widiasarana Informatika.

Amin Suyitno. 2008. Pendekatan dan Model Pembelajaran. Semarang : FMIPA

UNNES.

Arends, Richard I. 1997. Classroom Intruction and Management. United States of America : McGraw-Hill Companies. 
Arief S. Sadiman, R. Rahardjo, Anung Haryono, 1984. Media Pendidikan (Pengertian, Pengembangan dan Pemanfaatannya). Jakarta : PT. RajaGrafindo Persada.

Azhar Arsyad. 2005. Media Pembelajaran. Jakarta : PT rajaGrafindo Persada.

Budiyono.2003. Metodologi Penelitian. Surakarta: Sebelas Maret University, Press.

Budiyono. 2004. Statistik Untuk Penelitian. Surakarta: Sebelas Maret University Press.

Dimyati \& Mudjiono. 2006. Belajar dan Pembelajaran. Jakarta : Penerbit Rhineka Cipta.

Erman Suherman. 2001. Strategi Pembelajaran Matematika Kontemporer. Bandung : JICA-UPI.

Hamzah B. Uno.2006. Teori Motivasi dan Pengukurannya.Jakarta : PT Bumi Aksara.

Ira Kurniawati. 2003. "Pengaruh Metode Pembelajaran Kooperatif Jigsaw Terhadap Prestasi Belajar Matematika Ditinjau Dari Aktifitas Belajar Siswa Kelas II SLTP Negeri 15 Surakarta". Surakarta. UNS.

Joesmani. 1988. Pengukuran dan Evaluasi dalam Pengajaran. Jakarta : Departemen Pendidikan dan Kebudayaan.

Mohammad Nazir. 1988. Metode Penelitian. Jakarta : Ghalia Indonesia.

Mohamad Nur. 1999. Pemotivasian Siswa Untuk Belajar. Surabaya :Universitas Negeri Surabaya. 